\title{
Destination Branding: Brand Management and Brand Engagement of Health and Wellness Tourism in Thailand and the ASEAN Region
}

\author{
Jiraporn Prommaha ${ }^{a}$
}

\begin{abstract}
The 10 ASEAN (Association of Southeast Asian Nations) countries in Southeast Asia have been united for ASEAN community in 2015. Thailand is one of the members who take health and wellness tourism responsibility about tourism and product information, and health and wellness tourism standardization. Therefore, the researcher has studied in health tourism image in Thailand and ASEAN, because the image is significant cost to promote health and wellness tourism. They are factors that influence image management and also image attributes about health and wellness tourism in Thailand and ASEAN countries. In this study, the author aimed at the examination of influenced factors and the attributes for Thailand's and ASEAN's images of health and wellness tourism management and finding out the relations among cognitive, affective, and brand engagement in Thailand and ASEAN. This research could be used as guideline information for creation of plans and governmental policies of health and wellness tourism of Thailand and ASEAN region as well. The data obtained in this study included overall image and destination brand engagement, or personal engagement through way of life and daily life of Southeast Asian people. Southeast Asia has its uniqueness according to its slogan "ASEAN Southeast Asia: Feel the Warmth". This is considered as one of unique activities in health and wellness tourism. Tourists can have their direct experiences with unique tradition of each nation.
\end{abstract}

\section{Keywords}

Destination branding, brand management, brand engagement, health and wellness tourism

Tourism is a high growth industry. The tourism industry is a key role for economic system and Thailand society. It brings income, money, employment, and prosperity distribution to regions. Moreover, tourism takes part of transportation infrastructure development, also business and investment. When the country had an economic crisis, tourism brought income to country and faster recovered economic than other manufacturing factor and service. However, the tourism industry tends to be more competition, fast change, and sensitive without avoiding from the country's internal and external factors. The challenging situations and effects from changing for Thailand tourism were from many points (Ministry of Tourism and Sports 2011: 1).

The Health and Wellness Tourism in Thailand by Kasikorn Research Center (2012) stated that, the

\footnotetext{
aDhurakij Pundit University, Thailand

\section{Correspondent Author:}

Jiraporn Prommaha, Ministry of Tourism and Sports, No. 4 Rajadamnern Nok Avenue, Pom Prap Sattru Phai, Bangkok 10100, Thailand

E-mail: mots.gina@gmail.com
} 
health tourism was travelling and health activities. It was rapidly popular along a healthy trend. Many countries in Asia, included Thailand, have supported and expanded health tourism market. When the service free trade of ASEAN (Association of Southeast Asian Nations) Economic Community starts, the health tourism will be the significant factor for plenty of income, and will expand the investment market for Thailand. The advantages are cheap medical expenses, international standard treatment, and tourism resources and services.

Nowadays, people have emphasized on health care to avoid any diseases which will cause a lot of expenses on treatment. Therefore, the health operators have extended health services to cover both physical and mental, treatment, rehabilitation, and wellness.

In Thailand, the branding, brand image management, and brand engagement have not been seriously studied. The government and private sectors in Thailand have emphasized on overall tourism studying and image promoting. The results of this study would be supported the marketing and promoting plans for the country's image, and building and furthering selling points of health and wellness tourism in every aspect. However, the tourism market has increased competition, and the countries community has increased, such as ASEAN Community, the agencies had more responsibilities and work. Thailand even needed modern tools to cleverly access the tourists, especially the health and wellness tourists.

The destination branding related to image management and brand engagement concepts of health and wellness tourism, especially image which was associated with other factors: environmental factors. They could be personal factor in each tourist, or media factor which was inside psychological and social communications, or activated factors such as information resources, data distribution, and tourists' experiences (see Figure 1). Thence, the environmental studying could be a tool for more understanding and accessing to the tourists easily and clearly. The purposes of this study were as follows:

(1) To study the influenced factors for Thailand's and ASEAN's image management;

(2) To study the attributes of health and wellness tourism image of Thailand and ASEAN;

(3) To study the relations among cognitive, affective, and brand engagement of Thailand and ASEAN;

(4) To create plans and governmental policies of health and wellness tourism of Thailand and ASEAN.

\section{LITERATURE REVIEW}

The destination image management consisted of:

(1) Destination branding, destination image, and destination identity;

(2) Brand management, brand association, and brand engagement;

(3) The consumer choosing and behavior concepts.

Qu, Kim, and Im (2011) researched on a model of destination: integrating the concepts of the branding and destination image. They stated their three concepts as:

(1) Destination image studies;

(2) Traditional branding concepts;

(3) Practices.

They would like to create image theories to develop and test their tourism models. However, the branding theories were still limited.

That research emphasized on furthering the branding developing and testing a theoretical model of destination branding. Besides, those included significant concepts of the relations between destination image and brand association.

\section{BRAND IDENTITY MEANING}

Brand identity meant the differentiation itself from its competitors (Qu et al. 2011: 466-467). It came from the image and meaning of consumers or tourists inside their minds by two main points: 


\section{Conceptual Framework}

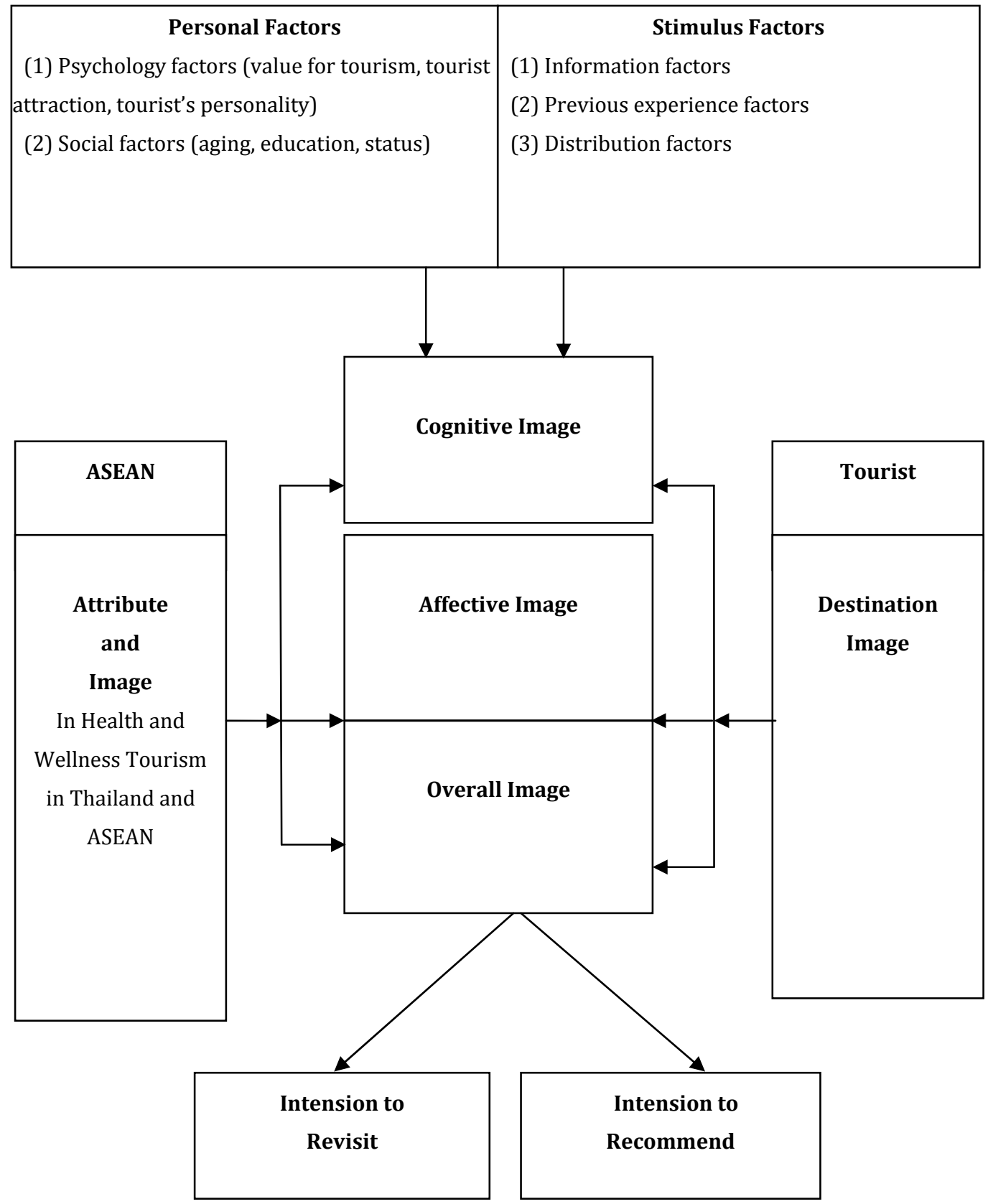

Figure 1. Conceptual Framework. 
(1) Knowledge about consumer's brand image;

(2) Positive and recognizable brand identity which finally led to brand engagement.

Branding identity needed to be created after realization of core identity and extended identity. Those two identities created brand's unique and differentiation from other competitors although the products were the same.

The core identity was embedded in each brand. It was brand's determination, standpoint, and eternity which were not changed; time could not influence its determination or standpoints to be ended. Its standpoint would be lasted as long as that brand existed (Mahidol University 2015).

The importance and composition of "brand identity" had the significant factor, brand identity structures, which consisted of two parts. They were:

The core identity showed a core of product. It was long lasting to the product: heart of brand. It told brand position, it was hard to change brand identity. The core identity consisted of factors which made product was unique and valuable. For example, the brand identity of "Michelin" had a core identity as safe drive (Wheeler 2009: 40). The Thai product, Jim Thompson, was number one product of Thai and foreigners when they thought about silk (Jim Thompson Fabrics 2015).

The extended identity was component which supported brand image to be unique and perfect. It created brand's feeling and reflected image and standpoint, for example, brand character, slogan, symbol, and product.

The profoundness of brand identity could be distinguished as two aspects: visible and tangible. The normal texts distinguished the five big frameworks (Boonyayotin 2012):

(1) Sight (the most efficiency sense);

(2) Sound;

(3) Touch;

(4) Smell;
(5) Taste.

For summarizing, the brand identity was in-mind image of consumer in each brand which was different from other competitors or places. Their image-in-mind came from positive thinking and unforgettable realization, those made relationship and brand engagement closely.

Therefore, "Brand is connection" meant, "brand created differentiation and business advantage of good or service. It was a media of value and uniqueness mixed with basic functional of product or service in consumer's perception".

The in-mind image of consumers based on each brand's differentiation: brand identity. It led to meaningful attitude perception of consumers: brand meaning. Those appeared as the clear destination image for tourists or consumers. The destination image $(\mathrm{Qu}$ et al. 2011: 467-468) has two parts. They were cognitive evaluation by consumers and affective evaluation by customers. When the author studied deeply, those relations were brand association which had three factors:

(1) Attributes were quality and appearance of brand to be recognized;

(2) Benefits were usefulness or worthiness which the consumers would get;

(3) Attitudes were value from brand which was evaluated by customers.

\section{THE RELATION OF BRAND MANAGEMENT}

The brand management was started by brand equity. It meant, the consumers value a brand, the consumers had good attitude of product's quality, and they liked that brand. The valuable branding could be done by Sriwattana Business Administration Technological College (2015):

Brand equity ultimately led to brand engagement. It could be generated based on the following elements (Siripullop 2015):

(1) Appreciation of quality; 
(2) Brand association;

(3) Awareness;

(4) Brand loyalty;

(5) Other proprietary brand assets.

\section{BRAND ATTITUDE OF CONSUMERS}

The brand attitude which happened by consumer's perception mainly came from internal consumer behavior or internal tourism behavior. Those related to brand image in consumer's perception. There were two main compositions:

(1) Cognitive image;

(2) Affective image (Qu et al. 2011: 467).

Nevertheless, when we considered the tourist attraction, the other factor which had to be considered was unique image; it created the perfection of overall image on that place.

\section{BRAND ENGAGEMENT}

Brand engagement (Fernández 2015) is the process of forming an emotional or rational attachment between a person and a brand. It comprises one aspect of brand management. What makes the topic complex is that brand engagement is partly created by institutions and organizations, but is equally created by the perceptions, attitudes, beliefs, and behaviors of those with whom these institutions and organizations are communicating or engaging with. Companies that create brand engagement get more loyal clients who are willing to pay an extra price for their products. They attract the best professionals in the market, investors interested in putting their savings in the firm and build a better brand image among the whole society.

Chamluck Khunpolkaew (2015) stated that, the consumers would feel like a part of the organization or brand, had owner feeling, frequently spoke up for brand. The consumer behavior has fast changed, who could get the customer insight needs first, would get customers first. If the good feeling was last embedded and hard to be imbedded, those goods and services have changed the relation status, distanced to closed, to be "engagement". Absolutely, that would not only happen for customers and employees also.

Gallup (Khunpolkaew 2015), the international company which has research network in the important cities in the world, has created research questions or methodology which were deep into attitude, feeling, and opinions of customers on organizations' goods or services. Gallup was accepted around the world. It has researched, developed model, and collected data from experiences and researches for a long time; Gallup could well answer the hiring organization. The Gallup Path, the model for customer engagement research, could explain people's decisions on each good and service. There were two main reasons: rational and emotional decision.

Thus, that tool was used to measure the relation or engagement levels between customers and services (the organization was included). There were four levels were look like pyramid. The lowest level was confidence. The customers would buy the goods or services of each brand when they were convinced that the products would be good as they hoped. The higher level was integrity. If the customers found any problems on the product, that problem needed to be solved. That good feeling would be developed to the next higher level: pride. They would proud and impressed. The highest level was passion. The customers would feel like they were part of that organization or brand. They would feel like the owner of the brand, frequently they spoke up for it when someone said something bad about the brand.

Although many organizations did not interest in feedback from customers to improve goods and services, they never noticed customers' gestures or expressions, or never done questionnaire, some organizations have continually surveyed customers' satisfaction and impressions on goods or organizations. Only few of these organizations have surveyed the 
engaged level: the most profoundly and reflection. The "engaged" would become loyalty customer in the end.

The four important parts which related to brand engagement were (Coach Ampol 2015):

(1) Confidence: trust creating to target group. It was trustworthiness and reliability of customers on the organization;

(2) Integrity: The morality of the organization had to be built. The customers needed to be felt and recognized that the organization was fair for them, management, administration, and treated to customers;

(3) Pride: customers' pride. This point was more important than the first two points. It was hard to be done and need a long time to create. If the organization could make this level happened, the customers would have brand loyalty;

(4) Passion: customer's passion of using product. It was the highest point which the organization needed to create. If the organization could reach this point, the customers would "love and engaged" with the organization, brand, goods, or services. The business would last long from these customers' expenses. That was the deepest and most effective level of "engaged" to be loyalty customer.

\section{METHODOLOGY}

This study emphasizes to research the 10 ASEAN countries: Brunei Darussalam, Cambodia, Indonesia, Lao PDR, Malaysia, Republic of the Union of Myanmar, the Philippines, Singapore, Thailand, and Vietnam, by using descriptive method. The data had mainly collected by:

(1) Documentary analysis;

(2) Qualitative research with in-depth interview (see Table 1).

\section{SCOPE OF THE RESEARCH}

(1) Interview the administrator group of government sector from ASEAN countries who supported health and wellness tourism in each country. The 10 chief executives of organizations and departments who directly responded were chosen to be interview: high representatives of Brunei Darussalam, Cambodia, Indonesia, Lao PDR, Malaysia, Republic of the Union of Myanmar, the Philippines, Singapore, Thailand, and Vietnam;

(2) The chief executives in Thailand who run private businesses about health and wellness tourism at least five years: 10 interviewees;

(3) The interview was done in October 2014 to January 2015.

\section{CONCLUSIONS}

(1) The influenced factors for Thailand's and ASEAN's image management. The image management and brand engagement of Thailand and ASEAN health and wellness tourisms could be said that, the tourism images management would mainly communicate via person, we can call "personal touch". Each country's personnel had his own identity, especially the service mind, easily smile, and kind to visitors, which created engagement to tourists and made them came back again. The using of health and wellness services again was included.

The fact findings were found from in-depth interviews of stakeholders as those within business Health and Wellness Tourism in Thailand (see Table 3). Feature that turns out to tourists or visitors can touching to experience the lifestyle of the local people, such as massage and pamper a million travelers can be found in the north of Thailand. The combination of wisdom Thailand using traditional life still visible today as massage kit lines (Nuad Kid-Sen) in the northeast of Thailand. The use of science and art that blends with the senses, taste, smell, sound and touch 5 which is in Thai Traditional massage nowadays; 
Table 1. Destination Branding for Health and Wellness Tourism: In-Depth Interview Scope

\begin{tabular}{|l|l|l|}
\hline Tools & Main informant & Topics of questions \\
\hline In-depth interview & $\begin{array}{l}\text { The influent factors for image management of health and wellness tourism in each country } \\
\text { The health and wellness tourism policies in each country } \\
\text { Attributes of health and wellness tourism image in each country } \\
\text { 1. High government officials who took } \\
\text { health and wellness tourism business in } \\
\text { Thailand. }\end{array}$ & $\begin{array}{l}\text { The effective communicative way of health and wellness tourism in each country } \\
\text { The obstructive factors of health and wellness tourism in each country } \\
\text { The attribute factors of health and wellness tourism image in Thailand } \\
\text { The effective communicative way of health and wellness tourism in Thailand } \\
\text { The effective media for health and wellness tourism in Thailand } \\
\text { The obstructive factors for health and wellness tourism in Thailand }\end{array}$ \\
\hline
\end{tabular}


Table 2. A Comparison of 10 ASEAN Countries in Terms of Their Branding of Health and Wellness Tourism

\begin{tabular}{|c|c|c|c|c|c|c|}
\hline Country & Strengths & Weaknesses & Brand identity & ASEAN's branding & Communication & $\begin{array}{l}\text { Communicative } \\
\text { problem/obstacle }\end{array}$ \\
\hline $\begin{array}{l}\text { 1. Brunei } \\
\text { Darussalam }\end{array}$ & $\begin{array}{l}\text { 1. Natural attractive } \\
\text { places } \\
\text { 2. Ancient cultural } \\
\text { tourism places } \\
\text { 3. Peaceful and easily } \\
\text { access country }\end{array}$ & $\begin{array}{l}\text { Brunei did not have its } \\
\text { own Brunei traditional } \\
\text { massage, just treated } \\
\text { massage for the } \\
\text { citizen. That was not } \\
\text { done seriously for } \\
\text { tourism. }\end{array}$ & $\begin{array}{l}\text { There was only one } \\
\text { department who took } \\
\text { responsibility on } \\
\text { health and wellness } \\
\text { tourism: Jerudong } \\
\text { Park Medical Centre } \\
\text { (JPMC). }\end{array}$ & Good tendency & $\begin{array}{l}\text { 1. Roadshows } \\
\text { 2. Seminars }\end{array}$ & $\begin{array}{l}\text { 1. The investment in health } \\
\text { and wellness tourism, } \\
\text { communication was not much. } \\
\text { Brunei has emphasized on } \\
\text { other tourisms, e.g., natural } \\
\text { and normal attractive places. } \\
\text { 2. In the future, it might be } \\
\text { serious discussions about that. }\end{array}$ \\
\hline 2. Cambodia & $\begin{array}{l}\text { 1. Cambodian } \\
\text { massage, spa, and } \\
\text { sauna by using } \\
\text { Cambodian herbs } \\
\text { 2. Politeness, smiles, } \\
\text { and gentle employees }\end{array}$ & $\begin{array}{l}\text { 1. The investment } \\
\text { from other sources of } \\
\text { investment fund was } \\
\text { needed on health } \\
\text { tourism and spa. } \\
\text { 2. More trains on } \\
\text { employees for more } \\
\text { services. }\end{array}$ & Quality control & $\begin{array}{l}\text { Possible tendency, but } \\
\text { the same and good } \\
\text { standardization }\end{array}$ & $\begin{array}{l}\text { 1. Other media such as } \\
\text { television and } \\
\text { magazine } \\
\text { 2. The real Cambodian } \\
\text { massages } \\
\text { demonstration to } \\
\text { tourists }\end{array}$ & $\begin{array}{l}\text { Less investment. Information } \\
\text { was limited. }\end{array}$ \\
\hline 3. Indonesia & $\begin{array}{l}\text { 1. Indonesian } \\
\text { traditional spa } \\
\text { 2. Nine position } \\
\text { massages and herbal } \\
\text { cover } \\
\text { 3. Local knowledge, } \\
\text { e.g., massages } \\
\text { position, herbs }\end{array}$ & $\begin{array}{l}\text { The health and } \\
\text { wellness tourism has } \\
\text { not promoted } \\
\text { nowadays, only for } \\
\text { "spa". }\end{array}$ & $\begin{array}{l}\text { Indonesian spa was } \\
\text { presented as } \\
\text { uniqueness, } \\
\text { traditional norms, } \\
\text { combined with custom } \\
\text { for value adding. }\end{array}$ & $\begin{array}{l}\text { Difficult tendency*. It } \\
\text { could be happened } \\
\text { with good methods. } \\
\text { The refinement and } \\
\text { punctiliousness of } \\
\text { ASEAN were } \\
\text { attractive. }\end{array}$ & $\begin{array}{l}\text { 1. Every channel, } \\
\text { printing and } \\
\text { electronic media } \\
\text { 2. Online } \\
\text { communication } \\
\text { 3. The association and } \\
\text { coordination of } \\
\text { governmental and } \\
\text { entrepreneur sectors, } \\
\text { association, private } \\
\text { business }\end{array}$ & $\begin{array}{l}\text { 1. The communicative was few } \\
\text { successful, especially the } \\
\text { meaning of "Indonesian Spa". } \\
\text { The tourists got confused what } \\
\text { was the real meaning of } \\
\text { "Indonesian Spa". } \\
\text { 2. There were many products } \\
\text { to be presented, promoting } \\
\text { products to tourists was } \\
\text { limited. }\end{array}$ \\
\hline
\end{tabular}




\begin{tabular}{|c|c|c|c|c|c|c|}
\hline 4. Lao PDR & $\begin{array}{l}\text { Laotian massages and } \\
\text { life style }\end{array}$ & $\begin{array}{l}\text { Lack of investment in } \\
\text { this kind of tourism. } \\
\text { Most of them were } \\
\text { family business. }\end{array}$ & $\begin{array}{l}\text { Minded services and } \\
\text { products }\end{array}$ & $\begin{array}{l}\text { Possible tendency. } \\
\text { The well tourism } \\
\text { activities would be } \\
\text { plenty. }\end{array}$ & $\begin{array}{l}\text { Depended on the } \\
\text { government's support }\end{array}$ & $\begin{array}{l}\text { The health and wellness } \\
\text { tourism coordination was } \\
\text { good, but should clarify the } \\
\text { detail. The clear enough } \\
\text { communication both content } \\
\text { and picture were needed to } \\
\text { prevent misunderstanding of } \\
\text { negative health and wellness } \\
\text { tourism. }\end{array}$ \\
\hline 5. Malaysia & $\begin{array}{l}\text { 1. Natural sources, } \\
\text { e.g., sky, rain forest, } \\
\text { and clean } \\
\text { environment, these } \\
\text { were good. } \\
\text { 2. The health tourism } \\
\text { expense was valuable } \\
\text { when compared with } \\
\text { Western countries. } \\
\text { 3. Hi-technology } \\
\text { treatment and capable } \\
\text { specialist. }\end{array}$ & Lack of branding & $\begin{array}{l}\text { Malaysia was trying in } \\
\text { branding by the close } \\
\text { discussion between } \\
\text { governmental and } \\
\text { private sectors. }\end{array}$ & \begin{tabular}{|l|} 
Quite difficult \\
tendency*. Each \\
country in ASEAN had \\
its own uniqueness.
\end{tabular} & $\begin{array}{l}\text { 1. Social media, } \\
\text { internet } \\
\text { 2. Printed and } \\
\text { electronic media }\end{array}$ & $\begin{array}{l}\text { The good branding was not } \\
\text { widely promoted because lack } \\
\text { of the corporation and attempt } \\
\text { to world market. }\end{array}$ \\
\hline $\begin{array}{l}\text { 6. Republic of the } \\
\text { Union of Myanmar }\end{array}$ & $\begin{array}{l}\text { Myanmar massage } \\
\text { with local herbs }\end{array}$ & $\begin{array}{l}\text { 1. Lack of realization } \\
\text { of natural resources } \\
\text { 2. Lack of private } \\
\text { sector corporation }\end{array}$ & $\begin{array}{l}\text { The health and } \\
\text { wellness tourism } \\
\text { branding was not } \\
\text { created, because there } \\
\text { were other types of } \\
\text { tourism for tourists. }\end{array}$ & $\begin{array}{l}\text { Possible tendency. } \\
\text { The high attempt to } \\
\text { reduce differences of } \\
\text { country development } \\
\text { was needed. }\end{array}$ & $\begin{array}{l}\text { Meeting and } \\
\text { framework } \\
\text { communication, e.g., } \\
\text { ASEAN, GMS (Greater } \\
\text { Mekong Subregion), } \\
\text { CLMV }\end{array}$ & $\begin{array}{l}\text { The tangible promotion on } \\
\text { health and wellness tourism } \\
\text { was not happened. }\end{array}$ \\
\hline 7. The Philippines & $\begin{array}{l}\text { 1. International } \\
\text { standardized } \\
\text { technology and } \\
\text { medical innovation. }\end{array}$ & $\begin{array}{l}\text { 1. Limited airline } \\
\text { 2. Limited in } \\
\text { transportation and } \\
\text { public facility for }\end{array}$ & $\begin{array}{l}\text { The branding was } \\
\text { built by corporations } \\
\text { among government, } \\
\text { hospital, hotel, }\end{array}$ & \begin{tabular}{|l|} 
Possible tendency. \\
The slogan of ASEAN \\
was "ASEAN Southeast \\
Asia Feel the
\end{tabular} & $\begin{array}{l}\text { 1. Printed and } \\
\text { electronic media } \\
\text { 2. Entrepreneur's } \\
\text { network }\end{array}$ & $\begin{array}{l}\text { 1. The clear definition of health } \\
\text { and wellness tourism was } \\
\text { needed. } \\
\text { 2. The specific market was }\end{array}$ \\
\hline
\end{tabular}




\begin{tabular}{|c|c|c|c|c|c|c|}
\hline & $\begin{array}{l}\text { 2. Educated and } \\
\text { special personnel. } \\
\text { 3. Facilities were } \\
\text { ready for service. } \\
\text { 4. The price was } \\
\text { reasonable when } \\
\text { compared with other } \\
\text { regions. }\end{array}$ & $\begin{array}{l}\text { transportation, e.g., } \\
\text { roads }\end{array}$ & $\begin{array}{l}\text { entrepreneurs, and } \\
\text { every related group. }\end{array}$ & $\begin{array}{l}\text { Warmth", that slogan } \\
\text { might strengthen } \\
\text { tourism brand. }\end{array}$ & 3. Travel and agencies & $\begin{array}{l}\text { needed for advertisement and } \\
\text { promotion, tangible success. } \\
\text { 3. The consensus between } \\
\text { governmental and private } \\
\text { sectors for the same direction } \\
\text { was needed. }\end{array}$ \\
\hline 8. Singapore & $\begin{array}{l}\text { 1. The new and } \\
\text { international } \\
\text { standardized medical } \\
\text { innovation. } \\
\text { 2. Educated and } \\
\text { specialized people: } \\
\text { specialist. }\end{array}$ & $\begin{array}{l}\text { 1. Lack of variety of } \\
\text { health and wellness } \\
\text { tourism. } \\
\text { 2. Lack of professional, } \\
\text { because the wage and } \\
\text { reward were not } \\
\text { attractive. }\end{array}$ & $\begin{array}{l}\text { 1. The serious } \\
\text { branding of health and } \\
\text { wellness tourism was } \\
\text { not happened, } \\
\text { because Singapore has } \\
\text { not had a strong } \\
\text { tradition of wellness } \\
\text { care or treatment. } \\
\text { 2. Singapore had } \\
\text { limited areas: } \\
\text { resources, climate, } \\
\text { and water, Singapore } \\
\text { needed to develop for } \\
\text { branding. }\end{array}$ & $\begin{array}{l}\text { Quite difficult } \\
\text { tendency*. } \\
\text { Each country had } \\
\text { different resource } \\
\text { cost, however, it could } \\
\text { be possible because } \\
\text { ASEAN had tourism } \\
\text { growth latency. }\end{array}$ & $\begin{array}{l}\text { Printed and electronic } \\
\text { media }\end{array}$ & $\begin{array}{l}\text { 1. The obstacle would not } \\
\text { happen with } 10 \text { countries if the } \\
\text { country had long history, } \\
\text { strong tradition; they would } \\
\text { get usefulness and had plenty } \\
\text { of communication to promote. } \\
2 \text {. The limitation might be } \\
\text { occurred with some countries } \\
\text { where the health and wellness } \\
\text { tourism experiences were } \\
\text { needed. }\end{array}$ \\
\hline 9. Thailand & $\begin{array}{l}\text { 1. Thailand was } \\
\text { successful in } \\
\text { traditional massage } \\
\text { (Thai massage) for a } \\
\text { long time. } \\
\text { 2. The mixture of local } \\
\text { tradition and Thai } \\
\text { wisdom. } \\
\text { 3. The reasonable }\end{array}$ & $\begin{array}{l}\text { The corporation } \\
\text { between Thailand } \\
\text { governments, the } \\
\text { clarified corporation } \\
\text { was needed. }\end{array}$ & $\begin{array}{l}\text { 1. Thailand has been } \\
\text { successful of health } \\
\text { and wellness tourism } \\
\text { branding because of } \\
\text { person (Thai's } \\
\text { personality). } \\
\text { 2. Tradition and } \\
\text { custom branding was } \\
\text { built via Thai identity }\end{array}$ & $\begin{array}{l}\text { Possible tendency. } \\
\text { Being member of } \\
\text { ASEAN Community } \\
\text { (AC) created support } \\
\text { and promote } \\
\text { information, and } \\
\text { human development }\end{array}$ & $\begin{array}{l}\text { 1. Printed and } \\
\text { electronic media } \\
\text { 2. Internet and social } \\
\text { media } \\
\text { 3. Entrepreneur's } \\
\text { network } \\
\text { 4. Agent or travel } \\
\text { agency } \\
\text { 5. Road show in }\end{array}$ & $\begin{array}{l}\text { 1. The different direction and } \\
\text { understanding of tourism that } \\
\text { made confusing to tourists. } \\
\text { 2. International standards } \\
\text { throughout the country were } \\
\text { needed. }\end{array}$ \\
\hline
\end{tabular}




\begin{tabular}{|c|c|c|c|c|c|c|}
\hline & $\begin{array}{l}\text { price when compared } \\
\text { with many areas. }\end{array}$ & & and life style. & & $\begin{array}{l}\text { Thailand and other } \\
\text { countries }\end{array}$ & \\
\hline 10. Vietnam & $\begin{array}{l}\text { 1. A long health } \\
\text { historical experiences } \\
\text { 2. Natural country } \\
\text { 3. Cheap expense and } \\
\text { lot of money value } \\
\text { 4. Effective and } \\
\text { modern sciences and } \\
\text { techniques }\end{array}$ & $\begin{array}{l}\text { 1. Vietnamese lacked } \\
\text { of perception } \\
\text { especially natural } \\
\text { treatment. } \\
\text { 2. The health and } \\
\text { wellness tourism was } \\
\text { new for Vietnam, } \\
\text { therefore there was } \\
\text { not any suitable } \\
\text { marketing strategies. }\end{array}$ & $\begin{array}{l}\text { 1. Vietnam had natural } \\
\text { hot springs and } \\
\text { outstanding health } \\
\text { products. } \\
\text { 2. The natural hot } \\
\text { springs were not } \\
\text { enough only for } \\
\text { tourism, they cured } \\
\text { and treated health } \\
\text { especially knee } \\
\text { arthritis patients. } \\
\text { 3. The puncture in } \\
\text { Vietnam has increased } \\
\text { famous around the } \\
\text { world. }\end{array}$ & $\begin{array}{l}\text { Possible tendency. } \\
\text { The extra researches } \\
\text { were needed } \\
\text { especially the content } \\
\text { and carefulness of } \\
\text { researched date. }\end{array}$ & $\begin{array}{l}\text { The health and } \\
\text { wellness tourism was } \\
\text { new for Vietnam, } \\
\text { therefore there was } \\
\text { not any suitable } \\
\text { marketing strategies. }\end{array}$ & $\begin{array}{l}\text { 1. Lack of destination } \\
\text { information of health and } \\
\text { wellness tourism in many } \\
\text { areas of Vietnam. } \\
\text { 2. The difficult communication } \\
\text { with local people especially the } \\
\text { city places. } \\
\text { 3. The facilities was needed to } \\
\text { be developed. } \\
\text { 4. An inconvenient } \\
\text { transportation/other } \\
\text { infrastructures. } \\
\text { 5. The health insurance was } \\
\text { not around the country. } \\
\text { 6. Some people might know } \\
\text { that Vietnam had "health and } \\
\text { wellness" resources, however, } \\
\text { it was difficult to persuade } \\
\text { local people or community, } \\
\text { because they lacked of medical } \\
\text { care. The medical care services } \\
\text { increasing were needed first } \\
\text { for them. } \\
\text { 7. The huge investment for sale } \\
\text { promotion and training people } \\
\text { about health and wellness } \\
\text { tourism were needed. }\end{array}$ \\
\hline
\end{tabular}

Note: ${ }^{*}$ The ASEAN countries with difficult unique branding for health and wellness tourism were Indonesia, Malaysia, and Singapore. Those three countries were outstanding in health and wellness tourism. 
Table 3. Private Sectors and Stakeholders of Health and Wellness Tourism in Thailand

\begin{tabular}{|c|c|c|c|c|c|}
\hline Business & Strengths & Brand identity & Communication & $\begin{array}{l}\text { Problem/ } \\
\text { Obstacle }\end{array}$ & $\begin{array}{l}\text { Expectations } \\
\text { of the government support }\end{array}$ \\
\hline $\begin{array}{l}\text { 1. Rarinjinda } \\
\text { Wellness Spa } \\
\text { Resort, Chiang Mai } \\
\text { Province }\end{array}$ & $\begin{array}{l}\text { Here is health spa, so we are } \\
\text { different from Day Spa; we } \\
\text { are completed spa. We have } \\
\text { a fresh water pool, Hydro } \\
\text { Therapy Pool, because the } \\
\text { area is plenty, we'll have } \\
\text { mineral tub also. } \\
\text { Apart from them, we also } \\
\text { have Vichy shower } \\
\text { treatment which is the new } \\
\text { spa innovation; we complete } \\
\text { have all. Sometimes, spa also } \\
\text { provides body script, body } \\
\text { massage, body aroma oil, but } \\
\text { we also have modern } \\
\text { equipment, hydro tub, Vichy } \\
\text { shower. }\end{array}$ & $\begin{array}{l}\text { The customers are fond of } \\
\text { our service. Each spa is } \\
\text { unique, but is not too } \\
\text { different from each other, } \\
\text { but the customers like our } \\
\text { services. Although you can } \\
\text { do massage well but you } \\
\text { don't have a good service, } \\
\text { the customer will not come. } \\
\text { The good product can't keep } \\
\text { the customers. Sometimes, } \\
\text { we can apply the service to } \\
\text { Thai's manners, customer } \\
\text { treat, Wai, saying Sawasdee, } \\
\text { giving smile when we } \\
\text { massage too hard and say } \\
\text { sorry politely: land of smile. } \\
\text { Customers impress a lot: } \\
\text { body treatment. }\end{array}$ & $\begin{array}{l}\text { We provide website and } \\
\text { agency contacts. The } \\
\text { customer base recently is } \\
\text { Chinese, then American. }\end{array}$ & $\begin{array}{l}\text { Now spa is well-known but } \\
\text { there are still some } \\
\text { misunderstandings about it. } \\
\text { I need more communication } \\
\text { about it. } \\
\text { Spa is a famous word. } \\
\text { Actually spa is from Spa the } \\
\text { Aqua: a water treatment. } \\
\text { Some places do not provide } \\
\text { any water, just massage, but } \\
\text { they still use Spa. Spa needs: } \\
\text { (1) enough area; and (2) } \\
\text { knowledge and expertise. } \\
\text { No matter what the name is, } \\
\text { the behavior reflects who } \\
\text { you are and what you do. }\end{array}$ & $\begin{array}{l}\text { I'm very thankful for the } \\
\text { government for any } \\
\text { trainings and public health } \\
\text { for entrepreneurs. Please } \\
\text { keep continue doing those. } \\
\text { However, the advertising is } \\
\text { very important. }\end{array}$ \\
\hline $\begin{array}{l}\text { 2. Tao Garden, } \\
\text { Chiang Mai } \\
\text { Province }\end{array}$ & \begin{tabular}{|lr} 
The philosophy does relate \\
to Mind & Spiritual, \\
adjusting, & in-depth \\
meditation, & customer \\
service, & employee \\
management, we need mind \\
for happier. \\
Being Green. Spa has started \\
from Europe and America. If
\end{tabular} & $\begin{array}{l}\text { Tao emphasizes on Thainess, } \\
\text { we willingly take care of the } \\
\text { customers by heart. The } \\
\text { service providers are Thai } \\
\text { who are amiable and } \\
\text { cheerful. }\end{array}$ & $\begin{array}{l}\text { Most of our customers are } \\
\text { foreigners because the } \\
\text { organizers and agencies are } \\
\text { in Europe. What customers } \\
\text { study here? } \\
\text { 1. Tao life styles. } \\
\text { 2. Anatomy. } \\
\text { 3. Massage } \\
\text { 4. About the emotion: How }\end{array}$ & $\begin{array}{l}\text { I think the problems are } \\
\text { about politics, the foreigners } \\
\text { don't trust Thailand's } \\
\text { security. Actually, the } \\
\text { internal problems are } \\
\text { meaningless, any diseases } \\
\text { come from your living styles. }\end{array}$ & $\begin{array}{l}\text { I'd like more support about } \\
\text { the convenient } \\
\text { transportation: visiting and } \\
\text { services. I prefer supports on } \\
\text { culture, ways of life, Thai } \\
\text { herbs, conservation, and } \\
\text { copyright registration. In the } \\
\text { future, the service and } \\
\text { traditional Thai medicine }\end{array}$ \\
\hline
\end{tabular}




\begin{tabular}{|c|c|c|c|c|c|}
\hline & $\begin{array}{l}\text { they don't live with their } \\
\text { family, many problems } \\
\text { would happen. We suggest } \\
\text { them to semi-Buddhism and } \\
\text { Tao: natural base, balancing, } \\
\text { emotional control. Tao } \\
\text { believes in energy } \\
\text { circulation, how do we use } \\
\text { it? How Tai Chi exercises? } \\
\text { How to balance yourself? If } \\
\text { you are small but you can } \\
\text { stand still when the 10 } \\
\text { people push you, how can } \\
\text { use that energy? You are } \\
\text { young and strong, you can } \\
\text { fight with any problems and } \\
\text { learning about yourself. }\end{array}$ & & $\begin{array}{l}\text { could they relieve } \\
\text { themselves. } \\
5 . \text { Emotional destroy: living } \\
\text { by themselves. } \\
\text { The customer can be divided } \\
\text { into: } \\
1.40 \% \text { is American. } \\
2.30 \% \text { is European. } \\
3.25 \% \text { is Asian. } \\
4.5 \% \text { is Thai. }\end{array}$ & & should be improved. \\
\hline $\begin{array}{l}\text { 3. Oasis Spa, } \\
\text { Chiang Mai } \\
\text { Province }\end{array}$ & $\begin{array}{l}\text { Oasis business is legally as } \\
\text { same as Day Spa. We open } \\
\text { every day since } 10 \text { am to } 10 \\
\text { pm. If we consider on } \\
\text { destination or health and } \\
\text { wellness tourism, we are like } \\
\text { Tao Garden or Rarinjinda; } \\
\text { we provide rooms and } \\
\text { detoxification. Tao has many } \\
\text { outstanding points: their } \\
\text { positions ransform } \\
\text { exercising positions. It is like } \\
\text { a treatment: retreating } \\
\text { themselves. }\end{array}$ & $\begin{array}{l}\text { About the brand. The word } \\
\text { Spa here (Chiang Mai) is } \\
\text { quite strong, we have our } \\
\text { own associations and Lanna } \\
\text { styles. Most of spa reflects } \\
\text { Lanna culture. I've been to } \\
\text { Spa in Bangkok and Samui } \\
\text { Island, massages were } \\
\text { different, however, the route } \\
\text { is the same: Thai massage. } \\
\text { The Thai massage is basic of } \\
\text { all massage. Many } \\
\text { workplaces there had to } \\
\text { adapt Thai massage to their }\end{array}$ & $\begin{array}{l}\text { Customer feedback. There } \\
\text { are many communicative } \\
\text { ways, we provide forms for } \\
\text { the customers. After finish } \\
\text { the massage, we'll sending } \\
\text { e-mail or thank you letter to } \\
\text { them for feedback checking. } \\
\text { Actually, it will be sent the } \\
\text { day after, if the customers } \\
\text { come here today, they will } \\
\text { get the e-mail tomorrow. } \\
\text { Oasis asks such as how's } \\
\text { going after massage. Does } \\
\text { anything we have to }\end{array}$ & $\begin{array}{l}\text { When the travel agencies } \\
\text { provide Spa, I think it's bad } \\
\text { for both of us. A tour guide } \\
\text { and massager are } \\
\text { conservative professions for } \\
\text { Thailand's wisdom. } \\
\text { Now Spa can be done by } \\
\text { money. They can use their } \\
\text { own staffs, taking care of } \\
\text { their customers, and then } \\
\text { the massage is destroyed. } \\
\text { Some customers said Thai } \\
\text { massage wasn't good; we } \\
\text { had to ask where did you get }\end{array}$ & $\begin{array}{l}\text { I'd like the government } \\
\text { sector support about the } \\
\text { road show, events, booths, } \\
\text { and TTM (Travel \& Tourism } \\
\text { Marketing) or TTF (Travel \& } \\
\text { Tourism Fair) marketing. } \\
\text { There were many visitors in } \\
\text { each activity, foreign spa } \\
\text { representatives and } \\
\text { agencies, Oasis will be last in } \\
\text { the market. } \\
\text { Therapist is a conservative } \\
\text { occupation. Some therapists } \\
\text { learn the job well and fly }\end{array}$ \\
\hline
\end{tabular}




\begin{tabular}{|c|c|c|}
\hline $\begin{array}{l}\text { Thai has significant services: } \\
\text { Thai manners and easily } \\
\text { smile. However, the } \\
\text { massages in each place are } \\
\text { different: "characteristic", } \\
\text { we have various races but } \\
\text { we have smile for every } \\
\text { services. }\end{array}$ & \begin{tabular}{|l|l} 
own identity. For here, our & improve? Do they have any \\
signature massage does not & suggestions? If the feedback \\
exist in other places. Such as & is good, it's ok, but if it's not, \\
fried shrimp with tamarind & we have to think about it. \\
sauce, many restaurants & $\begin{array}{l}\text { For example, it's too cold for } \\
\text { provide it, but here is }\end{array}$ \\
different. & the air-conditioner, too \\
For Oasis, the customers go & relavy massage, or no while massage. \\
back and tell others also. & When the customers give us \\
That's our heart, service is & more feedback, the customer \\
our work. We expect that the & service relation will send \\
customers will get 100\% of & those to spa massage. We \\
services from here. & $\begin{array}{l}\text { have to find out what was } \\
\text { going on within the next day } \\
\text { and reply back to the } \\
\text { customers within 24 hours. } \\
\text { If the feedback is good, we } \\
\text { both are happy, then we do } \\
\text { greeting welcome again. } \\
\text { We have many marketing, } \\
\text { the government sector } \\
\text { supports us events, booths, } \\
\text { sharing us to travel agencies. } \\
\text { The other marketing is hotel } \\
\text { staffs, they refer customers } \\
\text { to us. Most of the five-star } \\
\text { hotels in Chiang Mai provide } \\
\text { Spa in the hotel, but they still } \\
\text { send customers to us. If the } \\
\text { customers ask them where is } \\
\text { Oasis, Dhara Dhevi Hotel }\end{array}$
\end{tabular} & $\begin{array}{l}\text { abroad to work, the spa } \\
\text { therapists in Thailand will be } \\
\text { lack. Other foreigners cannot } \\
\text { do the good job as Thai does; } \\
\text { labor and lacking of } \\
\text { therapists will be a high } \\
\text { problem. If some of them } \\
\text { come back to Thailand, we } \\
\text { could say we're lucky. We } \\
\text { have to take the risk, I think } \\
\text { every spa faces this problem, } \\
\text { too. }\end{array}$ \\
\hline
\end{tabular}




\begin{tabular}{|c|c|c|c|c|c|}
\hline & & & $\begin{array}{l}\text { refers them here. The Oasis's } \\
\text { never told those hotels } \\
\text { referring us customers, but } \\
\text { we said we'd like to be their } \\
\text { options for Spa. If the staffs } \\
\text { suggest customers for Spa, } \\
\text { please recommend Oasis. } \\
\text { We have many marketing } \\
\text { about travel agencies also: } \\
\text { both of contacting them first } \\
\text { and they contacted us first. } \\
\text { Mostly, we focus the travel } \\
\text { agencies where used to } \\
\text { recommend us to customers. } \\
\text { The head office of Oasis is in } \\
\text { Chiang Mai, but the head } \\
\text { office of travel agencies is in } \\
\text { Bangkok. We have our } \\
\text { marketing representatives to } \\
\text { visit those travel agencies in } \\
\text { each province, we tell them } \\
\text { the new promotions. The } \\
\text { tourism trend is direct } \\
\text { booking, so we provide } \\
\text { online booking on our } \\
\text { website. }\end{array}$ & & \\
\hline $\begin{array}{l}\text { 4. Lanna Come } \\
\text { Spa, Chiang Mai } \\
\text { Province }\end{array}$ & $\begin{array}{l}\text { Lanna spa is a story. It's } \\
\text { about Mon spa, the } \\
\text { association advertises } \\
\text { northern spa to other } \\
\text { countries around the world. }\end{array}$ & $\begin{array}{l}\text { Thai massage is different } \\
\text { from other countries: more } \\
\text { Thai behaviors. We've taught } \\
\text { Thai massage to many } \\
\text { foreigners such as German. }\end{array}$ & $\begin{array}{l}\text { The road shows in other } \\
\text { countries, hotel contracts or } \\
\text { travel agencies have done. } \\
\text { The tourists come back here } \\
\text { a lot, some of them come }\end{array}$ & $\begin{array}{l}\text { In the future, we may ask } \\
\text { tourists about what do they } \\
\text { want except health and } \\
\text { wellness activities or spa } \\
\text { medical yoga meditation that }\end{array}$ & $\begin{array}{l}\text { In the future, I'd like the } \\
\text { government strengthen the } \\
\text { brand. We need budget to } \\
\text { support booth, road show, } \\
\text { marketing, school setting up, }\end{array}$ \\
\hline
\end{tabular}




\begin{tabular}{|c|c|c|c|c|c|}
\hline & & $\begin{array}{l}\text { We taught weighted massage } \\
\text { and manners such as soft } \\
\text { weighted massage and } \\
\text { speed. } \\
\text { We have Thai massage as a } \\
\text { culture. We've done } \\
\text { advertising, spa road show } \\
\text { in other countries. The Thai } \\
\text { massage is provided in small } \\
\text { shop, Thai absolute spa } \\
\text { provides Thai treatment: } \\
\text { Thai smells and products. } \\
\text { The significant cultures are } \\
\text { Thai people, aroma, Swedish } \\
\text { massage, and bamboo } \\
\text { massage. }\end{array}$ & $\begin{array}{l}\text { back here every year. We've } \\
\text { open the shop for eight } \\
\text { years, some customers } \\
\text { continually has come back } \\
\text { here for seven years, they } \\
\text { become friend and relative. } \\
\text { She is Karen from USA. She } \\
\text { comes here every year and } \\
\text { bought a condominium here. }\end{array}$ & $\begin{array}{l}\text { we provide. Do they want } \\
\text { cooking class or aerobic } \\
\text { dance? Do you want taking } \\
\text { therapist class? I think those } \\
\text { can be many activities. When } \\
\text { we talk about health and } \\
\text { wellness, some customers } \\
\text { have no idea what is it. } \\
\text { Wellness is similar to } \\
\text { medical wellness for them; } \\
\text { beauty is also. However, the } \\
\text { concept of Spa it does, day } \\
\text { spa, health relaxation, or } \\
\text { beauty, but we need to } \\
\text { specific what level of beauty. }\end{array}$ & $\begin{array}{l}\text { product line, or spa. Going } \\
\text { abroad is an advertising for } \\
\text { the state; road show support. } \\
\text { We have to do approach } \\
\text { strategy and we'll get the } \\
\text { specific customers. }\end{array}$ \\
\hline $\begin{array}{l}\text { 5. The Spa Resort, } \\
\text { Chiang Mai } \\
\text { Province }\end{array}$ & $\begin{array}{l}\text { This is destination resort. } \\
\text { Most of the package are } \\
\text { health: holistic health. Such } \\
\text { as package fasting, juicing it } \\
\text { which is drinking only juice, } \\
\text { raw food is a dish which is } \\
\text { cooked in less than } 43^{\circ} \mathrm{C} \text {. The } \\
\text { nutrients in fruit and } \\
\text { vegetable will last longer. It } \\
\text { depends on the kind of fruit } \\
\text { and juice. }\end{array}$ & $\begin{array}{l}\text { Why do we famous? The } \\
\text { answer is service mind. } \\
\text { Although our English is not } \\
\text { good, "smiling" service or } \\
\text { body gestures can show our } \\
\text { pleasures to serve them. } \\
\text { Those are our advantages, } \\
\text { Thai's advantages also. } \\
\text { The natural resource is also } \\
\text { important. This resort is on } \\
\text { the mountain and surrounds } \\
\text { with nature. Green brings } \\
\text { foreigners here. }\end{array}$ & $\begin{array}{l}\text { There is a lot of } \\
\text { word-of-mouth. Some } \\
\text { customers tell their friends. } \\
\text { The friends come here and } \\
\text { they like it, all of them come } \\
\text { here together within a year. I } \\
\text { think it's because the health } \\
\text { program in Chiang Mai is not } \\
\text { much, only for some spa. } \\
\text { We're small place and this is } \\
\text { our advantage: completed } \\
\text { spa. Word-of-mouth is } \\
\text { plenty, so we think we're } \\
\text { successful from it. The } \\
\text { guests might not many, but }\end{array}$ & $\begin{array}{l}\text { About the human } \\
\text { recruitment, we have } \\
\text { nutritionists to give advices. } \\
\text { Most of the employees are } \\
\text { local people, therapists come } \\
\text { from the same village. Now } \\
\text { we want to train our } \\
\text { employees. As I told the } \\
\text { owner's just changed, so the } \\
\text { change happens to } \\
\text { employees too. We realize } \\
\text { that some of them are lack of } \\
\text { knowledge, so we have to } \\
\text { train them to be skilled } \\
\text { employees. }\end{array}$ & $\begin{array}{l}\text { The government can do } \\
\text { whatever to support } \\
\text { personnel development. } \\
\text { That could be training or } \\
\text { seminar to strengthen } \\
\text { services and people are } \\
\text { talented. We've started } \\
\text { making our own product } \\
\text { such as coconut oil. We'd like } \\
\text { to have our own brand, the } \\
\text { natural base cream with no } \\
\text { chemical substances. } \\
\text { Now we can't produce our } \\
\text { product yet, we might have } \\
\text { to discuss it with the }\end{array}$ \\
\hline
\end{tabular}




\begin{tabular}{|c|c|c|c|c|c|}
\hline & & & $\begin{array}{l}\text { they are walk-in guests and } \\
\text { most of them were old } \\
\text { guests. We also provide in } \\
\text { the website. }\end{array}$ & $\begin{array}{l}\text { We'll find trainers for the } \\
\text { professional of our staffs. } \\
\text { The management might not } \\
\text { as same as the old owner. } \\
\text { We do emphasize on the } \\
\text { employee. }\end{array}$ & $\begin{array}{l}\text { producing factory. All } \\
\text { products; soap or shampoo, } \\
\text { have to be anti-SLS (Sodium } \\
\text { Lauryl Sulfate). We're } \\
\text { thinking about palm for next } \\
\text { product. Actually, the } \\
\text { boutique where selling our } \\
\text { brand as package, kit, or } \\
\text { provide detoxification } \\
\text { products could add value to } \\
\text { our brand. }\end{array}$ \\
\hline $\begin{array}{l}\text { 6. Dalharuenspa, } \\
\text { Khon Kaen } \\
\text { Province }\end{array}$ & $\begin{array}{l}\text { Thai massage, oil spa } \\
\text { massage, skin scrubbing, } \\
\text { treatment message, and } \\
\text { aroma massage. } \\
\text { customers are both Thai and } \\
\text { foreigner. For the foreigner } \\
\text { tourists, they like like-home } \\
\text { environment. Our shop } \\
\text { designs and decorates as a } \\
\text { home: cool and pleasant. } \\
\text { They are European and } \\
\text { American. }\end{array}$ & $\begin{array}{l}\text { Service is our heart. Smiling } \\
\text { staffs impress customers. } \\
\text { Some shops do good } \\
\text { massage but bad service, the } \\
\text { customers will not go that } \\
\text { place again. }\end{array}$ & $\begin{array}{l}\text { The customers know this } \\
\text { place via word-of-mouth. We } \\
\text { also provide website for } \\
\text { marketing. }\end{array}$ & $\begin{array}{l}\text { Our employees have to } \\
\text { practice English to explain } \\
\text { and communicate to tourists. }\end{array}$ & $\begin{array}{l}\text { Marketing support. The } \\
\text { tourism advertising is } \\
\text { needed for more northern } \\
\text { east visiting. }\end{array}$ \\
\hline $\begin{array}{l}\text { 7. Cheewatip Spa, } \\
\text { Khon Kaen } \\
\text { Province }\end{array}$ & $\begin{array}{l}\text { This place provides full } \\
\text { option of Day Spa. Our } \\
\text { massage styles are the same } \\
\text { for every therapist. The new } \\
\text { employees are needed to be } \\
\text { train for our message } \\
\text { positions. Our therapists } \\
\text { have Ministry of }\end{array}$ & $\begin{array}{l}\text { This place is a model of } \\
\text { northern east identical spa } \\
\text { from Ministry of Culture. The } \\
\text { identical spa or herbal ball } \\
\text { massage consists of five } \\
\text { senses. } \\
\text { Sight is northern east } \\
\text { traditional. You can see from }\end{array}$ & $\begin{array}{l}\text { We also provide brochures. } \\
\text { Most of the customers are } \\
\text { word-of-mouth that we do } \\
\text { health massage. Our massage } \\
\text { is mixing between Thai and } \\
\text { aroma massage. We also mix } \\
\text { with northern east massage; } \\
\text { "Nuad Kid Sen (push and stir }\end{array}$ & $\begin{array}{l}\text { The tour group sometimes } \\
\text { visits us but we cannot } \\
\text { handle with them all. Most of } \\
\text { the customers are our } \\
\text { members. }\end{array}$ & $\begin{array}{l}\text { I'd like the clearer } \\
\text { communication to tourists } \\
\text { for visiting northern east. } \\
\text { The government can } \\
\text { promote northern east } \\
\text { attractive places. The } \\
\text { northern east people are } \\
\text { kind, fun, and happy. Those }\end{array}$ \\
\hline
\end{tabular}




\begin{tabular}{|c|c|c|c|c|c|}
\hline & $\begin{array}{l}\text { Health certificate and } \\
\text { certificate from Department } \\
\text { of Employment. }\end{array}$ & $\begin{array}{l}\text { the decoration and clothes or } \\
\text { uniforms. } \\
\text { Taste is rosella juice and } \\
\text { herbal juice. The customers } \\
\text { can feel Thainess through } \\
\text { the drink. } \\
\text { Smell is massage oil smell } \\
\text { from northern east herbs. } \\
\text { Sound is music. Our music } \\
\text { has an enjoy rhythm. We } \\
\text { might improve it. } \\
\text { Touch is stirring nerves } \\
\text { massage. } \\
\text { It also comes from Thai } \\
\text { characteristics: gentle and } \\
\text { easily smile. Our massage is } \\
\text { sweet because we massage } \\
\text { carefully and focus on } \\
\text { services and treat. }\end{array}$ & $\begin{array}{l}\text { nerves)", and oil. The eight } \\
\text { rooms for massage are } \\
\text { prepared. }\end{array}$ & & $\begin{array}{l}\text { are our unique for } \\
\text { customers. }\end{array}$ \\
\hline $\begin{array}{l}\text { 8. Sukko Spa, } \\
\text { Phuket Province }\end{array}$ & $\begin{array}{l}\text { The outstanding advantage } \\
\text { is a private and effective } \\
\text { location for tourists. They } \\
\text { can feel silence here: the first } \\
\text { treatment. We have our own } \\
\text { products and songs for spa. } \\
\text { We applied both western } \\
\text { and Thai medical knowledge. } \\
\text { The western medicine } \\
\text { emphasizes on curing, the } \\
\text { eastern medicine focuses on } \\
\text { preventing. The western one }\end{array}$ & $\begin{array}{l}\text { Cultural preventing and } \\
\text { conservation. Thainess, Thai } \\
\text { image, and Thai wisdom are } \\
\text { Thai tradition which are } \\
\text { conserved. } \\
\text { For Sukko Spa, we have } \\
\text { Sukhothai period concept: } \\
\text { Phra Ruang ear. } \\
\text { The product marketing } \\
\text { should have an interesting } \\
\text { story such as Sukhothai } \\
\text { period. }\end{array}$ & $\begin{array}{l}\text { We have base customers and } \\
\text { also provide in the website. } \\
\text { We keep contact both Thai } \\
\text { and foreign travel agencies. } \\
\text { About the target group, it } \\
\text { depends on the tourists. } \\
\text { They are Malaysian, Russian, } \\
\text { and Korean. If you ask me } \\
\text { about the customer } \\
\text { planning, yes we'd like } \\
\text { Japanese. Most of the } \\
\text { customers come here with }\end{array}$ & $\begin{array}{l}\text { There are many Chinese } \\
\text { tourists in Phuket, they come } \\
\text { here a lot. For the } \\
\text { management, I think both } \\
\text { governmental and private } \\
\text { sectors have to take care of } \\
\text { the tourists together. Giving } \\
\text { information to them for their } \\
\text { happiness and also maintain } \\
\text { our natural resources. }\end{array}$ & $\begin{array}{l}\text { The government sector } \\
\text { should realize about the } \\
\text { higher tourism competition: } \\
\text { brand standard, illegal } \\
\text { hotels, no license. They may } \\
\text { also focus about the } \\
\text { personnel, migrant worker; } \\
\text { Thai will be employed. I } \\
\text { think Thai's quality of } \\
\text { education needs more } \\
\text { adjustment and } \\
\text { development. }\end{array}$ \\
\hline
\end{tabular}




\begin{tabular}{|c|c|c|c|c|c|}
\hline & is tangible. & $\begin{array}{l}\text { The concept was designed as } \\
\text { Sumeru mount where was } \\
\text { the heaven gate. The } \\
\text { paintings on the walls are } \\
\text { Three World. } \\
\text { Let our children know how } \\
\text { importance of Thainess, } \\
\text { being Thai, and Thai culture. } \\
\text { The significances of Thainess } \\
\text { are personality, sincerity, } \\
\text { and culture reflects the } \\
\text { image. The products are } \\
\text { Thainess. There is no } \\
\text { difference about the } \\
\text { massage. }\end{array}$ & $\begin{array}{l}\text { the tour group, someone has } \\
\text { visited here for } 18 \text { times. }\end{array}$ & & \\
\hline $\begin{array}{l}\text { 9. Angsana Laguna } \\
\text { Spa, Phuket } \\
\text { Province }\end{array}$ & $\begin{array}{l}\text { Our advantages are Laguna } \\
\text { Spa; we provide bathing } \\
\text { room after spa. We service } \\
\text { customer by bathing them, } \\
\text { body massage, and } \\
\text { scrubbing. For the scrub, our } \\
\text { scrubbed materials are } \\
\text { nature, and create new for } \\
\text { every scrubbing: fresh. The } \\
\text { difference from Banyan Tree } \\
\text { is our concept: Angsana. } \\
\text { Angsana flower is our } \\
\text { symbol, it blooms all year } \\
\text { long (In English, the Angsana } \\
\text { is flower) (Banyan tree is a } \\
\text { symbol of Banyan Tree). }\end{array}$ & $\begin{array}{l}\text { The service is different from } \\
\text { other places. We keep asking } \\
\text { customers while massaging, } \\
\text { herbal massage, or relaxing } \\
\text { before massage. Then we do } \\
\text { five-acupressure, lie on the } \\
\text { back and do herbal massage, } \\
\text { lie prone and back massage, } \\
\text { oil is used while massaging. } \\
\text { Scrubbing is before the } \\
\text { relaxing massage. After body } \\
\text { massage is facial massage. } \\
\text { The cost is about } 8,500 \text { baht. } \\
\text { We also provide Harmony: } \\
4 \text {-hand massage. The } \\
\text { scrubbing is done before }\end{array}$ & $\begin{array}{l}\text { We emphasize the human } \\
\text { communication. All } \\
\text { therapists are Thai and can } \\
\text { communicate well in English. } \\
\text { The specialist teaches } \\
\text { correct massage. There are } \\
12 \text { rooms, } 70 \text { employees, and } \\
4 \text { branches. We support } \\
\text { employees working in other } \\
\text { country branch and related } 7 \\
\text { hotels. All therapists are } \\
\text { Thai. }\end{array}$ & $\begin{array}{l}\text { Now } \text { Chinese tourists are a } \\
\text { lot that might cause reducing } \\
\text { of } \text { European tourists. } \\
\text { However, the internal } \\
\text { management in Angsana will } \\
\text { be created to support other } \\
\text { foreign tourists. }\end{array}$ & $\begin{array}{l}\text { The government should } \\
\text { support and promote } \\
\text { tourism, and I want more } \\
\text { peaceful politic. }\end{array}$ \\
\hline
\end{tabular}




\begin{tabular}{|c|c|c|c|c|c|}
\hline & $\begin{array}{l}\text { We have nail painting rooms } \\
\text { and hair salon (A chair for } \\
\text { toenail treatment can } \\
\text { massages in the same time). } \\
\text { The manicure can be done in } \\
\text { lay down position. }\end{array}$ & $\begin{array}{l}\text { normal massage. We have } \\
\text { products for customer's } \\
\text { buying. }\end{array}$ & & & \\
\hline $\begin{array}{l}\text { 10. Oasis Spa, } \\
\text { Phuket Province }\end{array}$ & $\begin{array}{l}\text { The trustworthiness, quality, } \\
\text { and standardized services } \\
\text { are built for customers. The } \\
\text { standard and service are } \\
\text { entire management: internal } \\
\text { management, and marketing. } \\
\text { Customers can reserve via } \\
\text { the center. We train our } \\
\text { employees for the same } \\
\text { standard in every branch. }\end{array}$ & $\begin{array}{l}\text { Organization management. } \\
\text { The employee could show } \\
\text { Thainess: Thai identity, } \\
\text { especially Thai herbs and } \\
\text { behaviors. The employee's } \\
\text { personality is like 90-minute } \\
\text { song massage. }\end{array}$ & $\begin{array}{l}\text { The target group (customer) } \\
\text { is all tourists who are } \\
\text { interested in health and } \\
\text { wellness. The employee } \\
\text { standard is level. Our service } \\
\text { standard is 93\% which is a } \\
\text { good standard (conclude } \\
\text { from the questionnaire). } \\
\text { The customers visiting, the } \\
\text { group customers visit us } 2-3 \\
\text { times a year. Most of visitors } \\
\text { tell others to come back } \\
\text { here. We also have every } \\
\text { advertisement for every } \\
\text { target group. }\end{array}$ & $\begin{array}{l}\text { Recruitment: whoever has } \\
\text { good attitude, interview, } \\
\text { lifestyle, family, skill testing. } \\
\text { We have to grow, increasing } \\
\text { branches, and to be standard } \\
\text { as best as we can. I think our } \\
\text { politics is an obstacle. The } \\
\text { government might have to } \\
\text { well manage about it. }\end{array}$ & $\begin{array}{l}\text { All government agencies and } \\
\text { departments should work at } \\
\text { the same direction. }\end{array}$ \\
\hline
\end{tabular}


(2) The attributes of health and wellness tourism image of Thailand and ASEAN. The scope of services in health and wellness tourism is not only limited to patients but also health tourists who need wellness and recreational services. Therefore, it is believed that tourists tend to visit any places where they can touch physical and psychological health. In other words, affective perception of tourists in Thailand reflects that branding in their mind and this process is deep as cognitive perception. It can be said that four elements of brand engagement in health and wellness tourism consist of:

(a) Confidence: Tourists have confidence on destination branding in Thailand;

(b) Integrity: Tourists can perceive clarity and integrity of service;

(c) Pride: Tourists have their pride when using service;

(d) Passion: Tourists have permanent passion for destination brand in Thailand.

In Thailand, the high costs were personnel, unique and outstanding Thai identity, that were strong selling points. Thailand brand was easily recognized by tourists. Moreover, Thai used "mind" in services, it was like a magnetic to tourists. They came back again and also told others to come, too. In addition, Thailand had strong point about money value, tourists could pay and got high profit. For example, admitting to world standard hospital but cheap expenses, health care, detoxification for healthy tourists, the convalescence patients could stay in Thailand for a long period because it was cheap. The byproduct of tourists was, they were able to directly choose the various places as they wanted;

(3) The relations among cognitive, affective, and brand engagement of Thailand and ASEAN. The image management and brand engagement of health and wellness tourism in Thailand and ASEAN on communication could be distinguished as three groups (see Table 2). They were:

Group 1 was Brunei Darussalam, Cambodia, Lao
PDR, Republic of the Union of Myanmar, and Viet Nam (CLMV). Those five countries did not emphasize on the communication nor health and wellness tourism images. They focused on the overall tourism in each country, e.g., cultural tourism or natural tourism. Therefore, the health and wellness tourism was not seriously promoted. Most of their budgets were spent on the overall tourism.

Group 2 was Philippines and Thailand. They were invested and image campaigned countries for image management and brand engagement of health and wellness tourism. However, Thailand had advantages on the facilities, road, airway, hotel, resident, restaurant, and various attractive places, easily transport throughout the country. The health and wellness tourism places had their own local uniqueness, Lanna Spa in the north, and spa in the south. Those were strong points for easily travelled by tourists. Nevertheless, the advantages of Philippines were, the personnel could well communicate in English. That was the strong point for tourists' understanding and ready to be back. Both Philippines and Thailand, the united branding for image management and brand engagement of health and wellness tourism in AEAN could possibly be happened. That would strengthen ASEAN brand. Furthermore, the development and ASEAN communication were needed for information exchange and best practice.

Group 3 was Indonesia, Malaysia, and Singapore. The three countries were ready and had strong points of health and wellness tourism branding for tourists to be accepted. They had their own identities of image management and brand engagement on health and wellness tourism. For example, Indonesia had Bali style spa, Malaysia had modern medical evolution. The tourists spent their money valuably in Malaysia. Singapore provided mixing puncture for treatment, and modern medical technology. Nevertheless, they stated that ASEAN branding was difficult to happen because each country had its own variety and 
resources. Each country had different investment costs of personnel resource, health and wellness tourism places readiness, and also technological and medical development. Therefore, the image management and brand engagement of ASEAN health and wellness tourism had to be developed.

The route of image management and brand engagement of health and wellness tourism in Thailand and ASEAN was rough. Being single brand needed long period of brand communication, because the communication investment for consumers or tourists and information stimulation were different. However, the country which had high capital on image tourism likes Thailand, tourists had good image with, could be easily developed. Moreover, health and wellness tourism in Thailand has influenced Thai health and wellness tourism's image. In other words, Thainess reflects via "person". The relation of cognitive image was direct experience which could be found in person, it is the main cultural factor which is transmitted from generation to generation by the word "Thais". Thainess is the most important factor for attracting tourists. Tourists' brand engagement derived from their affective image could reflect faith in Thainess, personal communication via Smile of Thailand, spirit to serve culture of Thai and Southeast Asian people, respect through pressing the hands together at the chest or forehead in sign of respect, showing respect and paying homage to their teachers before they commence massage, paying the respect to visitors, and Thai traditional costumes. For the image of health and wellness tourism in other Southeast Asian countries is characterized by their local massage and native herbs. Besides, important economic factors stimulating health and wellness tourism is value for money;

(4) To create plans and governmental policies of health and wellness tourism of Thailand and ASEAN. For governmental planning and policies of health and wellness tourism in Thailand in national and ASEAN levels, the private data showed that the government had to establish the central department which seriously ran and administrated on image management and brand engagement of health and wellness tourism. Now the governmental sector has not have person in charge of clarifying, planning, and running plans and policies. Nevertheless, the governmental sector has worked for systematic integration. Hence, the government sector had to do was multi-people-in-charge, the associate was needed. In the future, there would be discussion and established responsible department to be the center of image management and brand engagement of Thailand and ASEAN health and wellness tourism.

The suggestion for future research includes the use of mixed method, a combination of qualitative research and quantitative research. For qualitative research, data were collected through in-depth interview. For quantitative research, data were collected through questionnaire. The sample was tourists in Thailand and ASEAN countries. The data about factors affecting tourists' decision-making behaviors to choose health and wellness tourism in this region would be beneficial for future research.

\section{APPENDIX}

Name Lists of Interviewee from ASEAN Countries (Interview during January 25-30, 2015).

(1) Mr. Haji Khairuddin Abdul Hamid, Deputy Permanent Secretary, Ministry of Industry and Primary Resources, Brunei Darussalam.

(2) Dr. NEB Samouth, Secretary-General, Cambodia.

(3) Mr. Noviendi Makalam, Director for International Relations, Ministry of Tourism, Republic of Indonesia.

(4) Mr. Sounh Manivong, Director General, Tourism Develop Department, Ministry of Information, Culture and Tourism, the Lao People's Democratic Republic (Lao PDR).

(5) Datuk Dr. Ong Hong Peng, Secretary-General, 
Ministry of Tourism and Culture, Malaysia.

(6) Mr. Tint Twin, Director General, Ministry of Hotels and Tourism, Republic of Union of Myanmar;

(7) Mr. Rolando Carnizal, Assistant Secretary Office of Tourism Planning Development, Department of Tourism, the Philippines.

(8) Mr. Leong Yue Khong Lawrence, Assistant Chief Executive, Singapore Tourism Board, Singapore;

(9) Miss Wanna Chonpravet, Expert Level 9, Department of Tourism, Ministry of Tourism and Sports, Thailand;

(10) Dr. Ha Van Sieu, Vice Chairman, Ministry of Culture, Sports and Tourism, Vietnam National Administration of Tourism, Viet Nam.

Name Lists of Interviewee from Health and Wellness Tourism Stakeholders in Thailand (Interview during October 10-30, 2014).

(1) Wellness \& Spa Resort, Chiang Mai Province.

(2) TAO Garden, Chiang Mai Province.

(3) Oasis Spa, Chiang Mai Province.

(4) Lanna Come Spa, Chiang Mai Province.

(5) The Spa Resort, Chiang Mai Province.

(6) Dalharuen Spa, Khon Kaen Province.

(7) Cheewa Tip Spa, Khon Kaen Province.

(8) Sukkho Spa, Phuket Province.

(9) Angsana Laguna Spa, Phuket Province.

(10) Oasis Spa, Phuket Province.

\section{References}

Boonyayotin, K. 2012. Brand Identity. Retrieved March 3, 2015 (http://www.the agent.co.th/newsdetail.aspx?id=215).
Coach Ampol. 2015. Brand Engagement. Retrieved (http://coach-ampol.blogspot.com/2011/11/customer-engag ement-ce.html).

Fernández, A. 2015. 5 Brand Engagement Lessons From La Rioja. Retrieved (http://mktfood.com/en/blog/2015/02/22/ 5-brand-engagement-lessons-from-la-rioja/).

Jim Thompson Fabrics. 2015. Our Heritage. Retrieved (http:// www.jimthompsonfabrics.com/about-us/our-heritage).

Kasikorn Research Center. 2012. Retrieved March 11, 2015 (https://www.kasikorn research.com).

Khunpolkaew, C. 2015. Brand Engagement. Retrieved (http://www.prosoftcrm.in.th/ArticleInfo.aspx?ArticleTypeI $\mathrm{D}=2148$ \&ArticleID=9562).

Mahidol University. 2015. Brand Identity Meaning. Retrieved (http://inside.cm.mahidol.ac.th/mkt/index.php?option= com_content\&view=article\&id=337:-brand-identity\&ca tid=1:mk-articles \&Itemid=11).

Ministry of Tourism and Sports. 2011. National Tourism Development Plan B.E. 2556-2559. Bangkok, Thailand: Ministry of Tourism and Sports.

Qu, H., L. H. Kim, and H. H. Im. 2011. "A Model of Destination: Integrating the Concepts of the Branding and Destination Image.” Tourism Management 32(3):467-468.

Siripullop, K. 2015. Brand Management. Retrieved (http://www.bus.tu. ac.th/usr/kitti/brand.doc).

Sriwattana Business Administration Technological College. 2015. Brand Management. Retrieved (http://www.stech. ac.th/blogs/0216/wp-content/uploads/2011/09/Brand-Mana gement1.docx).

Wheeler, A. 2009. Designing Brand Identity. 3rd ed. New Jersey: John Willey \& Sons.

\section{Bio}

Jiraporn Prommaha, Ph.D. candidate, Philosophy of Communication Arts, Faculty of Communication Arts, Dhurakij Pundit University (www.dpu.ac.th), human resource officer, senior professional level at Ministry of Tourism and Sports, Thailand; research fields: public relations and human resources in Tourism Sector for Thailand and ASEAN. 